\title{
Heavy metal contamination in bottom sediments of saline endorheic lakes of Kulunda and Barabinsk steppes (Western Siberia, Russia)
}

\author{
Marina Kolpakova \\ Institute of geology and mineralogy SB RAS, 634000 Novosibirsk, Russia
}

\begin{abstract}
The article presents the results of assessment of heavy metals contamination in bottom sediments of saline lakes located on the territory of Kulunda and Barabinsk steppes of Western Siberia, Russia. The territory is characterized by large amount of lakes (more than 5000), including the Chany lake, which is the biggest lake of south of Western Siberia. By calculation the geochemical parameters, such as Enrichment factor, Contamination factor, Geoaccumulation index, Pollution load index, the common level of bottom sediments was classified as unpolluted. However, in comparison with average level of bottom sediment on that territory the lake sediments are enriched with the following elements: $\mathrm{Sr}>\mathrm{Rb}>\mathrm{Zn}>\mathrm{V}>\mathrm{Cr}>\mathrm{Ni}>\mathrm{Cu}>\mathrm{As}>$ $\mathrm{Pb}>\mathrm{Th}>\mathrm{U}>\mathrm{Mn}>\mathrm{Fe}>\mathrm{K}>\mathrm{Ti}$.
\end{abstract}

\section{Introduction}

According to [1], chemical elements from natural and anthropogenic sources can flow into aquatic ecosystems directly or through the atmosphere (for example, as a result of agro-economic work), while creating certain geochemical conditions of the environment that can accumulate or remove heavy metals from the system. Particular attention in connection with the pollution of heavy metals requires water bodies, the catchment area of which includes industrialized areas.

The main polluters in the southern part of Siberia are the enterprises of chemistry, petrochemistry, power engineering, municipal services and processing of agricultural products $[2,3]$. For example, in the Altai Territory, with the exception of two landfills for disposal (Altaihimprom OJSC (Yarovoye) and Slavgorod radio plant), there are no specially created sites for industrial and household waste, despite the fact that each year adds an edge about 400 thousand tons of household waste and 750 thousand tons of industrial waste. In addition, out of 1600 villages, only 20 have sewers with sewage treatment facilities [3].

The main substances that cause pollution of surface water in recent years remain sulfates, chlorides, general phosphorus, ammonium nitrogen, nitrates, fats, petroleum products, general iron and phenols volatile. In addition, it is possible to add chemical oxygen consumption 2-3 times higher than maximum permissible standards.

When it comes to lake ecosystems, which act as collectors of all these discharges and substances, the scale of the problem voiced within the projects becomes evident. Details of sources and activities in the territories are presented in the article.

\section{Regional overviews}

The research presented in this paper were carried out at the territory of Kulunda and Barabinsk Steppes (Altay and Novosibirsk regions, Russia) where more than 5000 saline lakes with total area about $4000 \mathrm{~km}^{2}$ are located [2]. The studied area forms an almost flat basin with a predominantly steppe landscape. The map of studied lakes presented in Fig. 1.

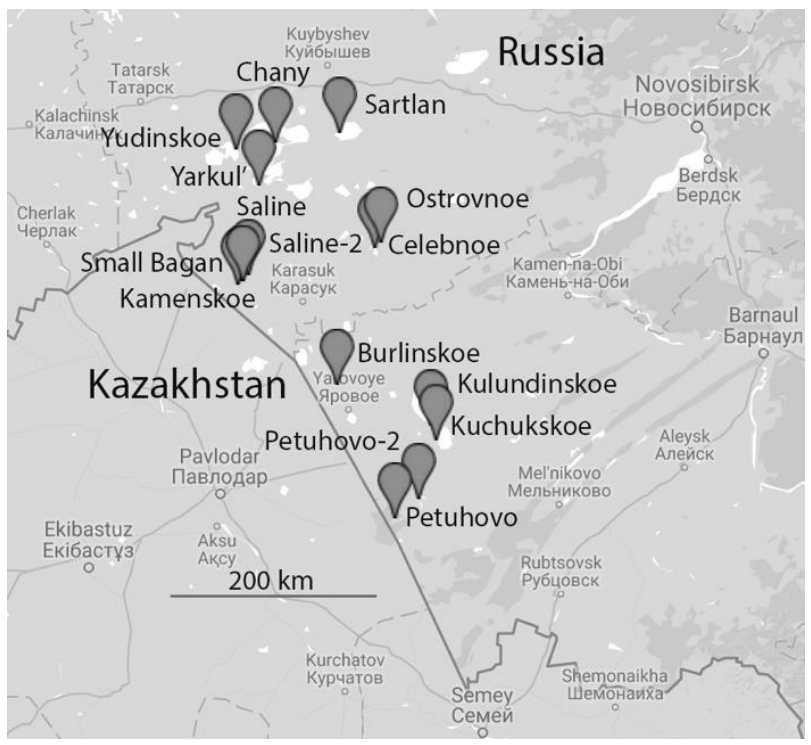

Fig. 1. Map-scheme of studied lakes 
The predominant anion in most lakes in the western part of the Kulunda steppe is a chloride ion (concentration range from 0.2 to $190 \mathrm{~g} / \mathrm{L}$ ). The content of carbonate components ranges from 0.5 to $4.3 \mathrm{~g} / \mathrm{L}$ : in soda lakes type its content reaches an average of 25 eq. $\%$ while its concentration in chloride lakes is only up to 0.8 eq. $\%$. The concentration of sulfate ions varies in different lakes from 0.09 to $65 \mathrm{~g} / \mathrm{L}$. The carbonates dominate in lakes with relatively low mineralized water and if the value of TDS is higher than $41.1 \mathrm{~g} / \mathrm{L}$ and $\mathrm{pH}$ more than 9.0. With the increasing of salinity and the decreasing of $\mathrm{pH}$ the anionic composition changes from $\mathrm{HCO} 3-\mathrm{Cl}-\mathrm{SO} 4$ to $\mathrm{Cl}-\mathrm{SO} 4-$ $\mathrm{HCO} 3$, what is more the increase in the chloride content is significantly ahead of the growth of sulfate. This is possible in the case of water saturation with respect to sulphate minerals (gypsum, thenardite, mirabilite, etc.) and their precipitation, as well as lack in accumulation of sulfates can be a result of its bacterial reduction.

Based on chemical composition, all studied lakes were divided into two large groups.

Water Type 1 (Cl-Na) chloride lakes with $\mathrm{Cl}$-ions in dominance. Chloride lakes are the most widespread type $(50 \%)$ among all studied lakes. Value of TDS varies between 40 and $600 \mathrm{~g} / \mathrm{L}, \mathrm{pH}$ between 7.2 and 9.4. This is the most saline type of lakes and the least alkaline in Kulunda steppe. Malinovoe lake - the most saline lake of Kulunda steppe - is included in this type (highest TDS is $560 \mathrm{~g} / \mathrm{L}$ (2011), pH is 8.4 (2014)). Among the cations, sodium prevails (average is 74 eq.\%), magnesium in waters of this type is somewhat larger than in soda and is equal to 26 eq. $\%$.

Water type 2 (Cl-Na with $\mathrm{HCO} 3$ up to 30 eq.\%) chloride lakes with high soda amount $(\mathrm{Cl}>50 \%$, $\mathrm{HCO} 3+\mathrm{CO} 3$ up to $30 \%$ ) Even a small amount of soda in water can provide high $\mathrm{pH}$ values. As can be seen from the picture, these two types have the similarities in major ions distribution. The difference is only in $\mathrm{CO} 3, \mathrm{SO} 4, \mathrm{Cl}$ and $\mathrm{Mg}$ accumulation.

The trace element composition of the lake waters of the Altai Territory is of undoubted interest from the point of view of their hydromineral resources. Among the trace elements in lake waters, elevated boron contents (up to 78 $\mathrm{mg} / \mathrm{L}$ ), bromine (up to $820 \mathrm{mg} / \mathrm{L}$ ), lithium (up to 3.6 $\mathrm{mg} / \mathrm{L}$ ), strontium (up to $13 \mathrm{mg} / \mathrm{L}$ ), iodine up to $6.3 \mathrm{mg}$ $/ \mathrm{L}$ ), arsenic (up to $0.6 \mathrm{mg} / \mathrm{L}$ ).

\section{Methods and materials}

The major components of water samples were analyzed at the "Voda" Accredited Center of Tomsk Polytechnical University (Tomsk) following the methods described in the literature. The contents of trace elements were analyzed on an Agilent 7500a ICP MS at the Institute of Solid State Chemistry and Mechanochemistry, Siberian Branch, Russian Academy of Sciences; Li was determined using a Varian AA 280 FS spectrometer.

In order to estimate the level of accumulation of chemical elements in bottom sediments of lakes several geochemical parameters including following indexes.
Enrichment factor (EF) was calculated as a ratio of element normalized concentrations between studied sample and reference data [4] by following equation [5]:

$$
E F=\frac{\left(\frac{C_{n}}{F e}\right)_{\text {sediment }}}{\left(\frac{C_{n}}{F e}\right)_{\text {reference }}}
$$

where $\mathrm{Cn}$ is a concentration of chemical element $\mathrm{n}$ in bottom sediments. All calculations were made in comparison with geochemical background data for Western Siberian Platform [4]. The normalization of chemical elements was conducted on iron content. Assessment criteria for EF suggested by [5]: indicated no enrichment $(\mathrm{EF}<1)$, minor enrichment $(1<\mathrm{EF}<3)$, moderate enrichment $(3<\mathrm{EF}<5)$, significant enrichment $(5<\mathrm{EF}<10)$, severe enrichment $(10<\mathrm{EF}<25)$, very severe enrichment $(25<\mathrm{EF}<50)$, and extremely severe enrichment $(\mathrm{EF}<50)$.

Geoaccumulation index (Igeo) was calculated as [6]:

$$
I_{\text {geo }}=\log _{2}\left[C_{n} /\left(1,5 \times B_{n}\right)\right] \text {, }
$$

where $B_{n}$ is an average element concentration [4]. Seven classes of Igeo are determined by [6]: unpolluted ( $0 \leq$ Igeo), unpolluted to moderately polluted $(0 \leq$ Igeo $\leq 1)$, moderately polluted $(1 \leq$ Igeo $\leq 2)$, moderate to strongly polluted $(2 \leq$ Igeo $\leq 3)$, strongly polluted $(3 \leq$ Igeo $\leq 4)$, strongly to extremely polluted ( $4 \leq$ Igeo $\leq 5)$, and extremely polluted (Igeo $\geq 5$ ).

The level of element contamination was estimated by the contamination factor (CF) [7] as a ratio between the metal content in the sediment sample and background values [4]:

$$
C F=C_{\text {sample }} / C_{\text {background }},
$$

where $\mathrm{CF}<1$ indicates low contamination; $1<\mathrm{CF}<3$ is moderate contamination; $3<\mathrm{CF}<6$ is considerable contamination; and $\mathrm{CF}>6$ is very high contamination

Contamination degree $(\mathrm{Cd})$ of bottom sediments was defined as a sum of all [8]: low contamination degree $(\mathrm{Cd}<6)$, moderate contamination degree $(6 \leq \mathrm{Cd}<12)$; considerable contamination degree $(12 \leq \mathrm{Cd}<24)$; very high contamination degree $(\mathrm{Cd} \geq 24)$.

Modified degree of contamination ( $\mathrm{mCd}$ ) was estimated according to the formula [9]:

$$
m C d=\frac{\sum_{i=1}^{i=n} C F}{n},
$$

The Pollution load index (PLI) [10] represents the number of times by which the heavy metal concentrations in the sediment exceeded the background concentration and give a summative indication of the overall level of heavy metal toxicity in a particular sample and is determined as the nth root of the product of nCF:

$$
P L I=\left(C F_{1} \times C F_{2} \times C F_{3} \times \ldots . . C F_{n}\right)^{1 / n},(5),
$$


where $\mathrm{CF}_{\mathrm{n}}$ is the $\mathrm{CF}$ value of element $\mathrm{n}$. The PLI values are interpreted into two levels as polluted (PLI $>1$ ) and unpolluted (PLI $<1)$.

The calculation of all indices was carried out with the normalization to background concentrations since the concentrations of many elements in the territory of Western Siberia are higher than their values for the upper continental crust.

\section{Results and discussion}

An assessment of the geological and geochemical factors affecting the formation of the geochemical balance of lakes has shown that the main sources of entry of elements into saline lakes are the underground and sewage waters of the drainage basins.

Fig. 2 indicates that enrichment factor for $\mathrm{Cu}$ is the highest between all heavy metals and varies from 2 to 9 , indicating that there is an anthropogenic source for that element. High enrichment for $\mathrm{Sr}$ is explained by salinization processes and formation of secondary minerals (Strontianite, Celestite). All other elements Ni, As, $\mathrm{Zn}$, Th, U show low level of enrichment (maximum 2-6) that shows the natural sources for them.

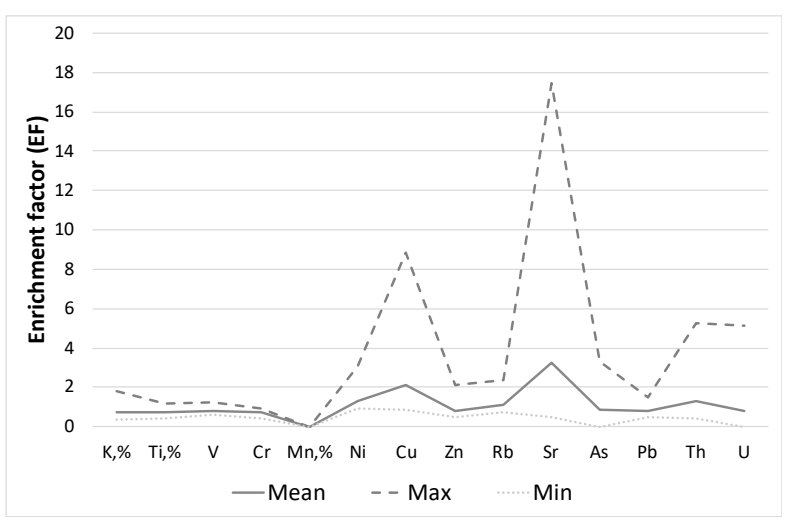

Fig. 2. Enrichment factor (EF) for chemical elements in bottom sediments of saline lakes of the south of Western Siberia

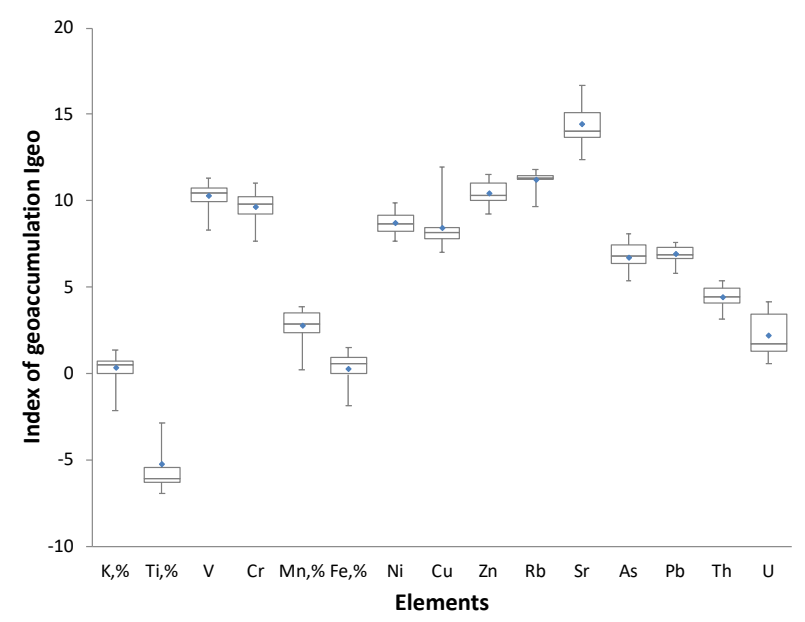

Fig. 3. Box-and-whisker plot of the geoaccumulation index of studied metals in 15 surface sediment samples of saline lakes

The estimation of geochemical indices of contamination of bottom sediments of lakes has shown that, based on the average values of the geoaccumulation index, the lake sediments are enriched with the following elements: $\mathrm{Sr}>\mathrm{Rb}>\mathrm{Zn}>\mathrm{V}>\mathrm{Cr}>\mathrm{Ni}>\mathrm{Cu}>\mathrm{As}>\mathrm{Pb}>\mathrm{Th}>$ $\mathrm{U}>\mathrm{Mn}>\mathrm{Fe}>\mathrm{K}>\mathrm{Ti}$ (Fig. 3).

Table 1. Contamination factors $\left(\mathrm{C}_{\mathrm{f}}\right)$, contamination degree $\left(\mathrm{C}_{\mathrm{d}}\right)$ and Pollution load index (PLI) for studied lakes

\begin{tabular}{|c|c|c|c|}
\hline \multirow{2}{*}{ Lake ID } & \multicolumn{2}{|c|}{$\begin{array}{c}\text { Contamination } \\
\text { degree }\end{array}$} & $\begin{array}{c}\text { Pollution } \\
\text { load index } \\
\text { (PLI) }\end{array}$ \\
\cline { 2 - 4 } & $\begin{array}{c}\text { Classic } \\
\text { (Cd) }\end{array}$ & Modified (Cp) & \\
\hline Petuhovo & 13.07 & 0.87 & 0.28 \\
\hline Petuhovo-2 & 11.45 & 0.76 & 0.37 \\
\hline Kulundinskoe & 7.71 & 0.55 & 0.26 \\
\hline Kuchukskoe & 3.03 & 0.23 & 0.09 \\
\hline Burlinskoe & 4.87 & 0.35 & 0.17 \\
\hline Saline & 11.80 & 0.84 & 0.39 \\
\hline Saline-2 & 11.25 & 0.75 & 0.39 \\
\hline Kamenskoe & 7.39 & 0.53 & 0.28 \\
\hline Small Bagan & 7.90 & 0.53 & 0.28 \\
\hline Ostrovnoe & 8.58 & 0.61 & 0.32 \\
\hline Celebnoe & 6.99 & 0.50 & 0.26 \\
\hline Chany & 12.61 & 0.84 & 0.45 \\
\hline Sartlan & 23.50 & $\mathbf{1 . 6 8}$ & 0.53 \\
\hline Yarkul' & 13.89 & 0.99 & 0.45 \\
\hline Yudinskoe & 16.85 & $\mathbf{1 . 3 0}$ & 0.56 \\
\hline & & & \\
\hline
\end{tabular}

Moreover, the extreme pollution level for this index is observed for the most part of the elements, including for $\mathrm{Rb}, \mathrm{Zn}, \mathrm{V}, \mathrm{Cr}, \mathrm{Ni}, \mathrm{Cu}, \mathrm{As}, \mathrm{Pb}$. Despite this, most of the lakes remain in the category of non-contaminated sites, with the exception of objects on the territory of which fishing, industrial or tourist activities are carried out (Chany, Sartlan, Yarkul Lakes, Table 1). A significant level of pollution is manifested mainly for $\mathrm{Cu}, \mathrm{Ni}, \mathrm{Fe}, \mathrm{U}$.

\section{Conclusion}

The results obtained in the framework of the project can be used by the authorities to manage the environment. The flow of various wastewater (industrial, economic, agricultural) into the lakes of Western Siberia, including underground and land flows, is the main source of pollution of lake water and precipitation. As preliminary recommendations, the authors of the project believe that the following approaches can be applied to preserve and prevent environmental pollution: 1. Develop a monitoring network to initiate preventive actions as part of the annual observations of the elemental composition of heavy metals in waters and bottom sediments. 2. Reduction of anthropogenic emissions. To this end, the ecological rehabilitation of the river waters of the region and the conduct of high-quality treatment of sewage entering them. 3. Prevention of direct entry of agricultural 
wastewater. 4. Minimizing the impact of the mobilization of metals in the environment by improving the quality of water through the extraction of highly polluted precipitation.

The data assessment and study were founded by Russian Science Foundation (RSF, Project 17-77-10086)

\section{References}

1. Holland HD, Turekian K. Geochemistry of Earth Surface Systems (Elsevier, 2010)

2. Borzenko SV, Kolpakova MN, Shvartsev SL, Isupov VP. Biogeochemical conversion of sulfur species in saline lakes of steppe Altai. Journal of Oceanology and Limnology, 36(3), 676-686 (2018)

3. Isupov VP, Kolpakova MN, Borzenko SV, Shatskaja SS, Shvartsev SL, Dolgushin AP, Lyakhov NZ. Uranium in the mineralized lakes of Altai Krai. Doklady Earth Sciences, 470(2), 1067-1070 (2016)

4. Strakhovenko VD, Shcherbov BL, Malikova IN, Vosel' Y. The regularities of distribution of radionuclides and reare-earth elements in bottom sediments of siberian lakes. Russian Geology and Geophysics, 51(11), 1167-1178 (2010)

5. Birth GA. A scheme for assessing human impacts on coastal aquatic environments using sediments. (Woodcoffe CD, Furness RA, Eds. Coastal GIS 2003)

6. Müller. Index of geo-accumulation in sediments of the Rhine River, Geo. J., 2,108-118 (1969)

7. Turekian KK, Wedepohl KH. Distribution of the elements in some major units of the Earth's crust, Geol Soc Am Bull 72: 175-192 (1961)

8. Hakanson L. An ecological risk index for aquatic pollution control.a sedimentological approach. Water Research, 14(8), 975-1001 (1980)

9. Abrahim GMS, Parker RJ. Assessment of heavy metal enrichment factors and the degree of contamination in marine sediments from Tamaki Estuary, Auckland, New Zealand, Environ. Monit. Assess 136: 227-238 (2008)

10. Harikumar PS, Nasir UP, MujeebuRahman MP Distribution of heavy metals in the core sediments of a tropical wetland system, Int J Environ Sci Technol 6: 225-232 (2009) 